\title{
Hepatitis and HIV Seropositivity among Healthcare Workers at Elazığ Oral and Dental Healthcare Center
}

\section{Elazıı̆ Ağız Diș Sağlığı Merkezi Çalıșanlarında Hepatit ve HIV Seropozitifliği}

\author{
๑ Gülden Eser Karlıdağ
}

Elazığ Fethi Sekin City Hospital, Clinic of Infectious Diseases and Clinical Microbiology, Elazığ, Turkey

\begin{abstract}
Objectives: In this study, we aimed to explore the prevalence of hepatitis B virus (HBV), HCV and Human immunodeficiency virus (HIV) infection, and anti-HBs and anti-HAV-lgG seropositivity among dentists, supporting healthcare staff and other staff working at Elazığ Oral and Dental Healthcare Center (ODHC).

Materials and Methods: Hepatitis B surface antigen (HBsAg), anti-HBs, anti-HCV, anti-HAV immunoglobulin G (lgG) and anti-HIV seropositivity status of all ODHC employees between January 1, 2016 and December 31, 2016 were analyzed retrospectively. Demographic data of all employees were recorded.

Results: Of 162 ODHC employees, 99 (61.91\%) were male and 63 $(38.09 \%)$ were female, and the mean age was $35.86 \pm 8.77$ years. Of the employees, 52 were dentists, 36 were nurses, 21 were dental prosthesis technicians and 53 from other various positions. None of the individuals were HBsAg, anti-HCV or anti-HIV positive. All individuals were anti-HBs positive and 96 (80.67\%) were antiHAV IgG positive. The lowest anti-HAV IgG positivity was found in dentists.

Conclusion: In our study, HBsAg positivity was found lower compared to general hospital rates, but comparable to those reported from ODHCs. This may be because our hospital is a local institution where infection prevention measures and training and vaccination activities are actively implemented. With this report, we intended to point out that zero infection and full vaccination is possible by improving training and enhancing awareness.

Keywords: Dental Healthcare Center, hepatitis, HIV, seropositivity
\end{abstract}

ÖZ

Amaç: Bu çalışma ile Ağız ve Diş Sağlığı Merkezinde (ADSM) çalışan diş hekimleri, yardımcı sağlık personeli ve diğer personelde hepatit $B$ virüs (HBV), HCV, Insan Bağışıklık Yetmezliği Virüsü (HIV) enfeksiyon sıkığını ve anti-HBs, anti-HAV- immünoglobulin (lgG) seropozitifliğini araştırmayı amaçladık.

Gereç ve Yöntemler: ADSM'de tüm çalışanların hepatit $B$ yüzey antijeni (HBsAg), anti-HBs, anti-HCV, anti-HAV lgG ve anti-HIV seropozitiflik durumları 1 Ocak 2016-31 Aralık 2016 tarihleri arasındaki veriler retrospektif olarak incelendi. ADSM çalışanların demografik verileri kaydedildi.

Bulgular: Çalışmaya alınan 162 ADSM çalışanın 99'u (\%61,91) erkek, 63'ü $(\% 38,09)$ kadın ve yaş ortalaması $35,86 \pm 8,77$ yıl idi. Bireylerin 52'si diş hekimi, 36'sı hemşire, 21'i diş protez teknisyeni ve 53'ü diğer çalışanlardı. Hiçbir bireyde HBsAg, anti-HCV ve antiHIV pozitifliği saptanmadı. Çalışan 162 bireyin tamamında anti-HBs pozitifti ve 96'sında $(\% 80,67)$ anti-HAV IgG pozitifliği saptandı. En düşük anti-HAV IgG pozitifliği diş hekimlerinde saptandı.

Sonuç: Çalışmamızda HBsAg pozitifliği genel hastane taramalarına oranla düşük fakat ağız diş sağlığı merkezlerinden verilen oranlarla benzerdir. Bunun nedeninin lokal bir hastane olması, enfeksiyon kontrol önlemlerinin özenli, eğitim ve aşılama faaliyetlerinin etkin yapııması olabilir. Bu çalışma ile eğitim ve farkındalığın artııılarak sıfır enfeksiyon ve tam aşılamanın mümkün olabileceğini sunmak istedik. Anahtar Kelimeler: Diş Sağlığı Merkezi, hepatit, HIV, seropozitiflik

Eser Karlıdağ G. Hepatitis and HIV Seropositivity among Healthcare Workers at Elazı̆̆ Oral and Dental Healthcare Center. Viral Hepat J. 2019;25:75-78. 


\section{Introduction}

Chronic Hepatitis B Virus (HBV) infection is reported to affect 257 million in the worldwide and Approximately 71 million people worldwide are chronically infected with Hepatitis C Virus (HCV) $(1,2)$. HBV and HCV transmission occurs through parenteral contact, sexual contact, horizontal, nosocomial or perinatal transmission $(2,3)$. Prevalence of HBV and HCV among the general population in Turkey are reported to be $4 \%$ and $1 \%$, respectively, with variances across the regions (4).

Tens of millions of people are estimated to be infected with Hepatitis A virus (HAV) across the world each year. Hepatitis A prevalence is closely associated with socio-economic development levels, led by indicators such as geographical differences, hygiene and other healthcare conditions (5). Turkey ranks among the countries with intermediate-endemicity (prevalence 8-88\%) (6).

Healthcare workers, in their professional routine, often come into contact with infected patient material such as blood and body fluids. This causes them to be more commonly exposed to bloodborne disease factors. HBV alone can also be transmitted by saliva. Depending on the serum level, HBV is identified 1.000 to 10.000 times less in saliva, however, high rates are also seen in saliva in line with higher serum levels (7). According to the World Health Organization $(\mathrm{WHO})$ data more than 85 million healthcare workers across the globe are injured by contaminated medical instruments (8). Hepatitis B vaccine is an effective method to protect from $\mathrm{HBV}$. There is, however, no vaccine available for $\mathrm{HCV}$, therefore, standard precautions come forth as the most effective ways to avoid the risk of transmission among patients and between patients and healthcare workers (9).
In this study we aimed to explore the prevalence of HBV, HCV, Human immunodeficiency virus (HIV) infection and anti- hepatitis B surface (HBs), anti-HAV-immunoglobulin G (lgG) seropositivity among the employees, including the dentists, the supporting healthcare staff and other positions working in Centers for Oral and Dental Healthcare Center (ODHC) outside of general hospitals. We expect that the results of this study will both contribute to the epidemiological data in Turkey and help to determine the efficacy of infection control measures implemented in the involved healthcare institutions.

\section{Materials and Methods}

All workers at the state ODHCs active in Elazığ were included in the study, and the data of $162 \mathrm{ODHC}$ workers that were recorded from 1 January to 31 December 2016 for hepatitis B surface antigen (HBsAg), anti-HBs, anti-HCV, anti-HAV-lgG and anti-HIV seropositivity were retrospectively examined. Demographic data were recorded and individuals with recurrent condition were excluded. Approval for the study was taken from Firat University, Ethics Committee (approval number: 05/04, date: 2019).

\section{Statistical Analysis}

The data of the ODHC workers included in the study were reviewed by age, gender, position (dentist, nurse, dental prosthesis technician, clerk, security guard, IT administrator or manager).

Serologic values for HBsAg, anti-HBs, anti-HAV-lgG, anti-HCV, anti-HIV were tested on Architect i2000 SR (Abbott, USA) device with the Chemiluminescent Microparticle Immunoassay method.

Table 1. Distribution of hepatitis $B$ surface antigen, anti-hepatitis $B$ surface, anti-Hepatitis $A$ virus-immunoglobulin $G$, anti-Hepatitis $C$ Virus and human immunodeficiency virus seropositivity in the Oral and Dental Healthcare Center workers

\begin{tabular}{|c|c|c|c|c|c|}
\hline & Dentist, n (\%) & Nurses, $\mathbf{n}(\%)$ & Prosthesis technicians, $\mathbf{n}(\%)$ & Others, $\mathbf{n}(\%)$ & Total, n (\%) \\
\hline Age & $33.65 \pm 9.27$ & $37.61 \pm 8.90$ & $32.33 \pm 8.71$ & $38.24 \pm 7.30$ & $35.86 \pm 8.71$ \\
\hline \multicolumn{6}{|l|}{ Gender } \\
\hline Female & $23(44.2)$ & $22(61.2)$ & $3(14.2)$ & $15(28.3)$ & $63(38.09)$ \\
\hline \multicolumn{6}{|l|}{ HBsAg } \\
\hline \multicolumn{6}{|l|}{ Anti-HBs } \\
\hline Positive & $52(100 \%)$ & $36(100 \%)$ & $21(100)$ & $53(100)$ & $162(100)$ \\
\hline Negative & $0(0)$ & $0(0)$ & $0(0)$ & $0(0)$ & $0(0)$ \\
\hline \multicolumn{6}{|l|}{ Anti-HCV } \\
\hline Positive & $0(0)$ & $0(0)$ & $0(0)$ & $0(0)$ & $0(0)$ \\
\hline Negative & $52(100)$ & $36(100)$ & $21(100)$ & $53(100)$ & $162(100)$ \\
\hline \multicolumn{6}{|c|}{ Anti-HAV-IGg } \\
\hline Positive & $23(56.09)$ & $25(96.15)$ & $9(81.8)$ & $39(95.12)$ & $96(80.67)$ \\
\hline Negative & $18(43.91)$ & $1(3.85)$ & $2(18.2)$ & $2(4.88)$ & $23(19.33)$ \\
\hline
\end{tabular}


The data were analyzed using the SPSS 22.0 software package. The Pearson's chi-square test was used for intergroup differences and significance limit was set at $p<0.05$.

\section{Results}

The study included 162 ODHC workers with a mean age of $35.86 \pm 8.77$ years of whom $99(61.91 \%)$ were male and 63 (38.09\%) were female. Of the 162 workers 52 were dentists, 36 were nurses, 21 were dental prosthesis technicians, and 53 of other positions such as clerk, security guard, IT administrator and manager (Table 1).

The available data included HBsAg, anti-HBsAg, anti-HCV and anti-HIV test results for all 162 workers that were included in the study. None of the individuals were HBsAg, anti-HCV or anti-HIV positive. All 162 workers were anti-HBs positive.

Out of the 162 ODHC workers (43 ODHC workers had no antiHAV-lgG testing), 119 were tested for anti-HAV-lgG and only 96 (80.67\%) were found anti-HAV-lgG positive. Review by profession showed that $25(96.15 \%)$ of the nurses, 39 (95.12\%) of the individuals from various other positions, $9(81.8 \%)$ of the dental prosthesis technicians, and $23(56.09 \%)$ of the dentists were antiHAV-lgG positive. The lowest anti-HAV-lgG positivity rate was found among the dentists, with statistically significant difference between this group and the nurses, dental prosthesis technicians and other positions groups $(p<0.001)$. Furthermore, no statistically significant differences were found in terms of anti-HAV-lgG positivity based on age and gender among the ODHC profession groups.

\section{Discussion}

In 1992, WHO and the International Labor Organization acknowledged HBV an occupational disease factor (10). In 1996 the Turkish Ministry of Health initiated the program that aims to screen healthcare workers for this virus and vaccinate if seronegative (11). HBV transmission in healthcare workers often occurs through contact with blood. Healthcare workers other than doctors are in direct contact with patients, hence in indirect contact with infected blood and blood products (12).

Even though lumen needles are often held responsible for $\mathrm{HCV}$ transmission, blood splash into the conjunctiva and needles without lumen can also cause transmission. Despite these risks, however, the prevalence of HCV infection is not higher among healthcare workers than is in the general population. Out of all needle injuries experienced by healthcare workers, only 1-2\% are reported to be associated with needles from $\mathrm{HCV}$ infected patients (13).

As is the case across the world, in Turkey, too, improved sanitation and hygiene, and socio-economic development lead to a decline in the number of HAV cases in children, as well as an increase in the number of mindful adults (14). The disease has a severe clinical course in the later years compared to childhood years. In Turkey, risk groups are screened for $\mathrm{HAV}$, and seronegative persons are vaccinated. Furthermore, at the end of 2012 the Turkish Ministry of Health has included Hepatitis A vaccination among routine childhood vaccines (15).

$\mathrm{HBsAg}$ and anti-HBs positive rates among healthcare workers in Turkey were reported, each respectively, to be $1.28 \%$ and $88.3 \%$ by Uludağ Altun et al. (16), $0.9 \%$ and $86 \%$ by Korkmaz et al. (17), and $0.5 \%$ and $88.28 \%$ by Keçik Boşnak et al. (11).

In their 1993 survey which explored the approach of dentists to Hepatitis B vaccine, Külekçi and Kartoğlu (18) found a vaccination rate of $10 \%$ and the most common reason for non-vaccination to be negligence and indifference. Contrarily, another survey conducted among dentists in the years from 2004 to 2008 reports a vaccination rate of $90 \%$. This favorable change both reflects the increased knowledge and awareness related to protection from Hepatitis B among dentists and indicates the efficacy of the serologic screening and vaccination program put into effect in 1996 in Turkey. In the same survey, dentists ranked HIV as the most feared disease. Interestingly, 31\% of those who have been immunized with vaccination indicated Hepatitis B as their most feared disease (19). A 2006 survey conducted with 108 dentists in Italy found HBV transmission to be the most feared outcome (57\%) even after they were immunized with vaccination (20).

In a 2017 study that screened dental students, all (100\%) were found HBsAg-negative and $93.5 \%$ were found anti-HBs positive (21). A study conducted among the workers of the Kırıkkale ODHC in 2012 reports an HBsAg rate of $0.85 \%$ and an anti-HBs rate of $89.83 \%$ (22). In our study, none of the ODHC workers were found HBsAg-positive, whereas all were anti-BHs-positive. This result may be an outcome of the high vaccination rates seen in the recent years among dentists and ODHC workers.

Although WHO has indicated dentists to be at high risk for $\mathrm{HCV}$ transmission, studies show that the prevalence of $\mathrm{HCV}$ infection in this group is comparable to (1.2\%) (23) or lower than $(0.0 \%)(24)$ the general population. Anti-HCV positivity among the healthcare workers in Turkey is reported between $0 \%$ and $0.34 \%(11,16,17)$. Anti-HCV positivity and anti-HIV positivity among Kırıkkale ODHC workers were found to be $1.69 \%$ and $0 \%$, respectively. The authors (22), however, report that the positivity value was very close to the threshold value and this could turn out to be false positive in repeated tests. Similar to the results reported from Turkey, in our study, anti-HCV and anti-HIV positivity were not identified in ODHC workers.

WHO recommends implementing Hepatitis A vaccination programs as sanitary conditions improve in intermediate-endemicity regions where the disease has a severe course and the number of mindful adults increase (14). Korkmaz et al. (17) identified an antiHAV-IgG positivity rate of $71.7 \%$ among healthcare workers. In our study, anti-HAV-lgG positivity rate was $80.7 \%$ and immunization with vaccine were recommended to healthcare workers who were seronegative for HAV. We believe that the statistically significant low rate of anti-HAV-lgG positivity among dentists, compared to the other positions in the ODHC, may be due to their higher education and socio-cultural levels. A study conducted with dental students, the rate of anti-HAV-lgG positivity was found at $24.9 \%$ (21). Considering the mean age of the participants in our study, the rate may be assessed higher compared to the above study. Screening for HAV vaccination should be performed more diligently in the coming years.

Approximately 32.2-38.8 million people worldwide are infected with HIV. Heathcare workers cannot differentiate HIV-positive patients from the patient's history and physical examination. Therefore, all patients should accept blood and other body fluids 
potentially infected. Heathcare workers, should work according to standard precautions (25). The first case was reported in 1985 and 14695 cases have been reported until 31 December 2016 in our country (26). In our study, none of the ODHC workers were found HIV positive.

\section{Study Limitations}

The limitation of our study was the low number of cases and reflecting local data.

\section{Conclusion}

In the recent years, HBsAg positivity rates reported from oral and dental healthcare centers in Turkey are lower than those reported from general hospital screenings, while anti-HBs positivity rates are higher. In our study, too, HBsAg-positivity was found lower than that of the general hospital rates, but comparable to those reported from the ODHCs of these hospitals. In our study, we identified $100 \%$ anti-HBs positivity among ODHC workers a rate that has never been reported to date. This may be because our hospital is a local institution where infection prevention measures and training and vaccination activities are actively implemented. Nonetheless, that Hepatitis transmission is one of the most feared conditions among dentists may lead them to take special care personally aside from organized screening and training, hence be the reason for the rise seen in vaccination rates. The first step in preventing and protecting from viral hepatitis is to gain awareness about the condition. With this report we intend to point out that zero infection and full vaccination is possible by improving training and enhancing awareness.

\section{Ethics}

Ethics Committee Approval: Approval for the study was taken from Firat University, Ethics Committee (approval number: 05/04, date: 2019)

Informed Consent: Retrospective study.

Peer-review: External and internal peer-reviewed.

Financial Disclosure: The author declared that this study received no financial support.

\section{References}

1. Fact-sheet: hepatitis B [internet]. Geneva: World Health Organization; 2018. Available from: https://www.who.int/en/newsroom/fact-sheets/detail/hepatitis-b [cited 2018 Jul 18].

2. Fact-sheet: hepatitis C [internet]. Geneva: World Health Organization; 2018. Available from: https://www.who.int/en/newsroom/fact-sheets/detail/hepatitis-c [cited 2018 Jul 18].

3. Hou J, Liu Z, Gu F. Epidemiology and prevention of hepatitis B virus infection. Int J Med Sci. 2005;2:50-57.

4. Tozun N, Ozdogan O, Cakaloglu Y, Idilman R, Karasu Z, Akarca U, Kaymakoglu S, Ergonul O. Seroprevalance of hepatitis B and C virus infections and risk factors in Turkey: a fieldwork TURHEP study. Clin Microbiol Infect. 2015;21:1020-1026

5. Jacobsen $\mathrm{KH}$, Wiersma ST. Hepatitis A virus seroprevalence by age and world region, 1990 and 2005. Vaccine. 2010;28:66536657.

6. Kader C, Göçmen AY, Demir MI, Colak NY, Gök SE, Arkan Fl, Sara MY, Erbay A. Hepatitis A immunity in Yozgat, Turkey. Ann Saudi Med. 2019:39:37-41.
7. Van der Eijk AA, Niesters HG, Götz HM, Janssen HL, Schalm SW, Osterhaus $A D$, Man RA. Paired measurements of quantitative hepatitis $B$ virus DNA in saliva and serum of chronic hepatitis $B$ patients: Implications for saliva as infectious agent. J Clin Virol. 2004:29:92-94.

8. Prüss-Ustün A, Rapiti E, Hutin Y. Estimation of the global burden of disease attributable to contaminated sharps injuries among health-care workers. Am J Ind Med. 2005;48:482-490.

9. Anders PL, Drinnan AJ, Thines TJ. Infectious diseases and the dental office. N Y State Dent J. 1998;64:29-34.

10. Immunization of health-care workers: recommendations of the Advisory Committee on Immunization Practices (ACIP) and the Hospital Infection Control Practices Advisory Committee (HICPAC). MMWR Recomm Rep. 1997;46:1-42.

11. Keçik Boşnak V, Karaoğlan I, Namıduru M, Şahin A. Seroprevalences of Hepatitis B, Hepatitis C, HIV of the Healthcare Workers in the Gaziantep University Sahinbey Research and Training Hospital. Viral Hepatitis Journal. 2013;19:11-14.

12. Karslıgil T, Uygur O. Evoluation of HBV antibodies evoked by immunization and infection among health employee and population. Eur J Ther 2007;13:31-34.

13. Ray SC, Thomas DL. Hepatitis C. In: Mandell GL, Bennett JE, Dolin R, eds. Mandell, Douglas, and Bennett's Principles and Practice of Infectious Diseases. 8th ed. Philadelphia, PA: Churchill Livingstone Elsevier, 2015:1904-1927.

14. Franco E, Meleleo C, Serino L, Sorbara D, Zaratti L. Hepatitis A: Epidemiology and prevention in developing countries. World $J$ Hepatol. 2012;4:68-73

15. Türkiye Viral Hepatit Önleme ve Kontrol Programı https://hsgm. saglik.gov.tr/tr/duyurular/1169-türkiye-viral-hepatit-önleme-vekontrol-programı.html

16. Uludağ Altun H, Eraslan A, Özdemir G. Seroprevalences of HBV, HCV and HIV among healthcare workers in a secondary care hospital. Viral Hepatitis Journal. 2012;18:120-222.

17. Korkmaz $P$, Çevik Çağlan $F$, Aykın N, Alpay $Y$, Güldüren HM, DoğruYaşar Z, et al. Seroprevalences of HBV, HAV, HCV and HIV infection among health personnel in a state hospital. Klimik Journal. 2013;26:64-67.

18. Külekçi $G$, Kartoğlu Ü. Türkiye'de hepatit B aşısı ve diş hekimleri. I.Ü. Diş Hekimliği Fakültesi Dergisi. 1993;27:61-64.

19. Topcuoğlu N, Külekçi G. Compliance with recommended infection control procedures among Turkish dentists: Changes over a twoyear period. GÜ Diş Hek Fak Derg. 2009;26:155-161.

20. Fabiani L, Mosca G, Giuliani AR. Hygiene in dental practices. Eur J Paediatr Dent. 2006;7:93-97.

21. Kutlu R, Terlemez A, Karademirci MM. Evaluation of seroprevalence of hepatitis A and hepatitis B in dentistry faculty students. Konuralp Tıp Dergisi. 2018;10:41-47.

22. Avcıküçük H, Süzük $S$. The Seropositivity of hepatitis $B$, Hepatitis $\mathrm{C}$ and HIV of the healthcare workers in Kırikkale Mouth and Dental Health Center. Türk Mikrobiyol Cem Derg. 2013;43:144-148.

23. Brambilla E, Cagetti MG, Fadini L, Tarsitani G, Strohmenger L. Epidemiologic survey of medical and non-medical personnel in a public dental clinic. Ann Ig. 2005;17:155-162.

24. Nagao $Y$, Matsuoka $H$, Kawaguchi T, Ide T, Sata M. HBV and HCV infection in Japanese dental care workers. Int J Mol Med. 2008;21:791-799

25. Wyz gowski P, Rosiek A, Grzela T, Leksowski K. Occupational HIV risk for health care workers: risk factor and the risk of infection in the course of professional activities. Ther Clin Risk Manag. 2016;12:989-994.

26. Gökengin D. HIV infection in Turkey: How close are we to the target? Klimik Dergisi. 2018; 31(1):4-10 